\title{
Good Tax Governance: A Matter of Moral Responsibility and Transparency*
}

DOI 10.1515/ntaxj-2017-0005

Received May 13, 2017; accepted May 13, 2017

\begin{abstract}
Multinational corporations' tax practices are hotly debated nowadays. Multinationals are accused of not paying their fair share of taxes. Apparently, acting within the limits set by law is not sufficient to qualify as morally responsible behavior anymore.

This article offers ethical reflection on the current debate. The general public typically evaluates (aggressive) tax planning in moral terms rather than legal terms. Therefore, multinationals need to reflect on their tax planning strategy next to economic and legal terms also in ethical terms. This article addresses the relationship between society, morality and taxes. The concepts of tax planning, "aggressive tax planning”, "tax evasion” and "tax avoidance" are elaborated on to exemplify the difference between a purely legal and broader approach. In moral terms, aggressive tax planning may imply loss of integrity and trust which may entail certain costs for businesses, such as reputation damage. It will be argued that in order to improve corporate reputation and (moral) leadership, corporate social responsibility (CSR), endorsed by many corporations around the globe, is a helpful tool. Reflection on tax planning in the context of CSR - good tax governance - should foster a moral mind set and enhance accountability and transparency.
\end{abstract}

Keywords: multinationals, tax avoidance, aggressive tax planning, corporate moral agency, corporate social responsibility (CSR), Carroll's CSR Pyramid, transparency, Starbucks

\footnotetext{
*Corresponding Author: Hans J.L.M. Gribnau: Professor of Tax Law, Fiscal Institute and the Center for Company Law, Tilburg University; Professor of Tax Law, Leiden University, the Netherlands. The author can be reached at J.L.M.Gribnau@tilburguniversity.edu Ave-Geidi Jallai: PhD researcher, Fiscal Institute, Tilburg University. The author can be reached at A.G.Jallai@tilburguniversity.edu * The authors would like to thank the anonymous reviewers for their valuable feedback
}

\section{Introduction}

Multinationals' tax practices are the subject of much discussion nowadays. During the last decade, the amount of tax that multinational enterprises (MNEs) pay has become a subject of interest to much larger circles of actors than just the tax authorities. The media has been reporting stories about tax avoidance and/or companies not paying their "fair share" of taxes. For instance, the tax planning techniques used by Amazon, Starbucks and Google have gained particular focus. In addition, various nongovernmental organizations (NGOs), such as Tax Justice Network, ActionAid, ChristianAid and SOMO, have published critical reports on aggressive tax planning structures (see, e.g., James 2012, ActionAid 2012, Christian Aid 2013, SOMO 2015). Even consumers have shown interest in the amount of taxes paid by corporations (see, e.g., Bergin 2012, Kleinbard 2013).

It can therefore be said that multinational enterprises are currently in the eye of the storm. Their tax planning practices are claimed to be too aggressive and this has led to a public outcry. Politicians have shared this public sentiment, sometimes even accusing these multinationals of “immoral” behavior (see, e.g., UK HMRC 2012). There are no clear signs that the storm will calm soon because both national and international policymakers have set this issue high on their agenda (see, e.g., OECD BEPS, European Commission 2016a, UN 2016). What should multinationals do? Should they wait out the storm or can they still the waters?

The current debate on tax planning practices of multinationals shows that there is something inherent in tax planning that is not covered by the traditional legal distinction between (illegal) corporate tax evasion and tax avoidance. Aggressive tax planning is not discussed in terms of legal or illegal behavior, but in moral terms. Therefore, it requires ethical reflection. Multinational enterprises need to reflect on their tax planning strategy not only in economic and legal terms, but also in ethical terms. Therefore, this article addresses the relationship between society, morality and taxes (\$2). The next issue to be dealt with is that of moral agency $(\S 3)$. Morality regards 
the behavior of individuals, but does it also concern the behavior of businesses? Furthermore, the concept of tax planning is elaborated on, and the relationship between law and morality in relation to the concepts "aggressive tax planning”, "tax evasion" and "tax avoidance" will be discussed (\$4). Taxes are a cost item for a business enterprise, which indicates that companies need to mitigate that. On the other end, too aggressive a tax planning burdens the society with costs, and moreover, may imply certain costs for business, such as reputation damage, for example (§5). It will be argued that in order to improve corporate reputation and regain public trust, corporate social responsibility (CSR) is a helpful tool.

Currently, many companies embrace CSR, which entails several kinds of obligations towards the society ( $\$ 6)$. The question is, however, whether a business' CSR should also reflect (moral) leadership in relation to its tax strategy? Moreover, does the ethical obligation to go beyond what is required by the law - key to CSR companies - encompass, for instance, tax transparency? These questions structure this article. It will be argued that in light of CSR, good tax governance should enhance accountability and transparency. In this regard, in $\S 7$, making a distinction between an intrinsic motivation to do the right thing (with a favorable reputation as an upshot) and extrinsic motivation (such as concern for favorable reputation in order to boost shareholder value) will be proposed.

As for methodology, this article first explores theoretical literature on morality in order to argue that corporate tax planning has a moral dimension to it and subsequently to better understand the extent of moral responsibility of corporate entities in relation to their tax planning practices. Further, the (empirical) research on corporate reputation is studied for understanding one of the possible reasons why corporations should be motivated to reconsider their tax planning behavior. As a last step, the normative element of this article proposes CSR as a possible solution for more ethical corporate tax behavior. Thus, this is an interdisciplinary research. Naturally, this article is a subject to several limitations. First, the existing empirical research on corporate tax planning, tax ethics and reputation is scarce. Second, the normative part on taxation in the context of CSR is dealt with in a rather summarily way and theoretical details and discussions are therefore ignored. Therefore, this article should be seen as a first step and invitation for further research.

\section{Society Involves Morality}

Taxes are contributions to society. In this regard, society can be seen as "a cooperative venture for mutual advantage [...] typically marked by a conflict as well as by an identity of interests", in the famous words of the political philosopher John Rawls (Rawls 1999, 4). Elaborating on famous seventeenth century social contract theorists such as Thomas Hobbes and John Locke, Rawls argues that social cooperation "is always productive and without cooperation there would be nothing produced and so nothing to distribute" (Rawls 2001, 61). Cooperation, of course, regards a specific kind of relation between individuals; those engaged in this system of social cooperation rely on one another to do their part. Here, morality comes in, for morality addresses not only the question as to how one ought to live as an individual, but also how individuals interact with other individuals. In addition to the question of a good life (i.e., "how should I live?"), there is the issue of a good society ("how should we live as a society?"). We focus on the latter.

Being a part of the society entails moral rights and obligations. The central question of morality then is how one should live in relation to other individuals. How should we treat other individuals in society and take into account their interests - and not only our own interests? (Bloomfield 2007, 3-4). It is not just about what is normal to do, but what is proper and (morally) right to do. What is good behavior towards others and what is the good society to which one should aspire? Other individuals are "others with whom we interact personally, as well as those more distant who may be affected by what we do", in the words of the moral philosopher Paine $(1996,478)$. However, while it is necessary to consider others' interests, morality does not demand that one does this at the expense of one's own personal needs and aspirations. Moral agents may see to their own interests or the interest of their families as having special standing (Bloomfield 2007, 3). A moral point of view does not require that individuals behave in an altruistic way, but rather that they see their personal interests, objectives and ideals in relation to those of other individuals in society.

Thus, morality is about how one ought to act. Studying ethics concerns the philosophical inquiry, for example, to obtain clarity on moral problems and to resolve them 
in an ethically satisfactory way (Callahan 1988,7$).{ }^{1}$ Morality can be seen as a public system, in the sense that there is shared understanding and knowledge about how one should act, and that it is not irrational to be guided and judged by that common morality. But unlike, for example, the legal system, morality is an informal public system (that all impartial persons could accept): "it has no authoritative judges and no decision procedure that provides unique answers to all moral questions" (Gert 1998, 11). This informal system covers "those practices and activities that are considered importantly right or wrong; the rules that govern those activities; and the values that are embedded, fostered, or pursued by those activities and practices” (De George 1999, 19). But the term "morality" also covers principles, ideals and virtues. Thus, this informal public system that governs behavior affecting other persons including moral rules, principles, values, ideals and virtues, may, however, entail conflicting and competing demands. The moral philosopher Callahan (1988) illustrates this with regard to conflicting moral values. Moral problems involve questions of value. Moral issues involve value dilemmas: the protection or furthering of one value or a set of values inevitably demands the sacrifice of some other value or a set of values. And not to decide in favor of one value or a set of values is "equivalent to deciding in favor of the competing value or set of values" (Callahan $1988,7)$. These moral issues should not be handled in an opportunistic way; values, principles, etc., should not simply be dusted off on occasion.

Paine focuses on the importance of principles and values. She argues that moral thought can be usefully distinguished in two - related and overlapping - levels (Paine 1996, 480). First, there is "principled thinking”: individuals "need a moral framework of principles and values for routine use in their daily lives" (Paine 1996, 479). ${ }^{2}$ This regards often rather intuitive, unreflective moral thinking, but not necessarily so; it may also involve deliberation. Routine actions and deliberation, however, should be based on systematic moral reflection. There is therefore also a second, "critical" level: people need a method or strategy to select these principles for routine use on an everyday basis and to deal with conflicts among them. At the first level, the choices of individuals should be guided by

\footnotetext{
1 Ethics studies morality (De George 1999, 19). The philosophical study of morality is called ethics or moral philosophy, although often the terms "moral" and "ethical" are used interchangeably.

2 She follows Hare's distinction between two levels of moral thinking: an intuitive level (rephrased by Paine as principled thinking) and a critical level from which to select, evaluate and adjudicate between the first-level practices and principles (Hare 1992).
}

general moral principles or values which are used as a kind of filter. These general principles of principled thinking are twofold: they encompass general principles of social morality, on the one hand, and the special principles associated with social roles that individuals occupy or with personal ideals, on the other.

Solidarity, responsibility and reciprocity are examples of general principles. In a (international) tax context, some (special) principles that may spring to mind are the equality principle (level playing field), the fairness principle and the single tax principle. Principled thinking provides guidance for everyday life. It guides one's decisions when one chooses to act in a certain way because it is one's duty, or if one will help someone in need, or one will advance an important ideal. Of course, principled thinking can also prohibit a course of action because it would be deceptive, unfair, unlawful, a breach of trust, a violation of rights and so on. As stated above, day-to-day principled thinking should be preceded by critical reflection. At this second, critical level, another mode of moral thinking is involved. Individuals should anticipate the consequences of alternative choices, achieve a sympathetic understanding of the interests of those affected and identify the course of action likely to do the best. The interests of each affected party should be considered impartially (Paine 1996, 480). In this context, tax-related questions include: how does one's minimal, but legal, compliance affect other individuals, and what impact might this kind of minimalist compliance have on the provision of public goods such as infrastructure, education and health care. This kind of compliance is seen as aggressive tax planning (see §4). This affects others for an individual's tax burden is shifted to other individuals in the society (distributive justice), or the budget is dented causing less public goods and therefore diminishing the well-being of others. Morality clearly requires taking into account these kinds of interests of other individuals.

\section{State, morality and the law}

The stability of social cooperation is preserved by the coercive powers of government in modern society where people are often perfect strangers. Government nowadays provides the institutional conditions making modern civilization and economic activity possible. Consequently, government is substantially responsible for the kinds of lives including their options and choices that members of an existing community can lead (Murphy and Nagel 2002, 4142). An elaborate legal system is a part of this institutional 
framework that supports and enables social cooperation. It regulates relationships between members of society and thus ensures a degree of mutual trust (Rawls 1999, 206-211; Gribnau 2017a, 40-41).

The legal system contains rights and obligations. This also goes for taxation. The legislature determines that the share taxpayers have to contribute to society and "translates" this in tax laws. The obligation to contribute to society has nowadays crystallized out in a large number of very complex legal rules containing detailed provisions of taxpayers' obligations and rights.

In passing we note that liberals like Rawls, Murphy and Nagel, argue for far more government intervention and public goods than is palatable to libertarian philosophers such as Nozick. Libertarians claim that freedom from human restraint is necessarily good and constraints by others are only justified to prevent the imposition of greater human constraints. According to Nozick, the state should thus restrict itself to protecting every person's right to freedom from coercion which prevails over all other rights and values. This minimal "state is inspiring as well as right" (Nozick 1974, ix). For him, the redistributive taxes are a form of coercion, even theft. This is quite an extreme position. "Taxation of earning from labor is on a par with forced labor" (Nozick 1974, 169; see however Faulkner 2017). Given the high level of taxation in Western liberal states financing all kinds of public goods and redistributive policies, libertarian taxpayers will probably try to minimize their tax liability, which is to their mind based on unjustified laws for they are levied by a state which to their minds interferes too much with personal liberty. ${ }^{3}$

In both a liberal and minimal (libertarian) state, the taxpayers' rights and obligations are laid down in a system of legal rules. Paying taxes as a moral obligation owed by members of a community to their community is in this way transformed in an elaborate legal system. The legal system is thus to be seen as "an institutionalization or codification" of ethics into specific principles, rules, regulations, proscriptions and procedures (Crane and Matten 2007, 5). However, different choices with regard to the use of the system of tax rules impact others and society at large in different ways. This inevitably implies the moral question: What is good behavior towards others? So, though the (formal) legal system consists of "codified ethics" and is distinguished from the (informal) ethical system, it does not

3 To complicate things there also so-called left-libertarians who endorse certain "state-like" activities that "classical" right-libertarians reject (see Duff 2005 and Cohen 2001, 169-175). We will not elaborate on this position and the attitude towards tax it entails. exhaustively codify morality. Ethical responsibilities are therefore not exhaustively codified in the law. With respect to tax planning, moral questions have to be addressed because tax law is often not a matter of hard, fast and unequivocal rules. The legal system is inevitably imperfect. Legal rules can be used and complied with in different ways, with different moral impacts. Phrased in general and abstract terms, their application to particular situations is necessarily often unclear. Furthermore, gaps in the law are a common phenomenon. Moreover, there is often a (moral) choice between different legal rules, and rules can be manipulated. Interpreting and using the law, therefore, inevitably implies making value judgments (Gribnau 2015, 239-240). Thus, although both morality and law regard human behavior, they are to be distinguished. The law does not exhaust morality. People may take actions that are good and legal, although the law does not require them to do so. Many multinationals, for instance, do not make use of child labor in their factories in developing countries, even though child labor is legal in some of these countries (Fisher and Lovell 2009, 46). Companies may, for example, accept moral obligations towards (external) stakeholders, stretching these obligations beyond the legal claims of their shareholders (Freedman 2006, 46). ${ }^{4}$ With regard to tax planning, (corporate) taxpayers may take a less aggressive stance than minimization - within the boundaries of the (letter of the) law. ${ }^{5}$ This suggests that companies can be seen as moral actors. Whether this really is so and to what extent businesses bear moral responsibility towards others, that is, the society, will be discussed next.

\section{Businesses and Moral Agency}

As stated, the central problem of morality is traditionally framed in the question as to how one should live in relation

4 These last kinds of obligations account for the category "actions that are legal but not necessarily just”, for some writers (e.g., Milton Friedman) argue that there are no obligations on a corporation other than to obey the law and meet the demands of the shareholders. There is no need to point out that there are other moral views on the corporation - a specific kind of cooperation - for parties other than shareholders may also be affected by the actions of a business, which creates some kind of moral responsibility (see Jallai and Gribnau 2017). 5 Here we use the term 'letter of the law' as shorthand with regard to tax planning that exploits the technicalities or differences between tax systems by making use of "a bewildering variety of techniques (e.g., multiple deductions of the same loss, double-dip leases, mismatch arrangements, loss-making financial assets artificially allocated to high-tax jurisdictions)”(Piantavigna 2017, 52). 
to other individuals. Society consists of individuals and organizations, among which are also businesses. Companies contribute to the society, for example, in the form of products, services, employment and taxation. Like individuals, businesses interact with other (corporate) persons and thus affect others (i.e., stakeholders, such as consumers or creditors) and benefit from their actions. Companies benefit from society at large, from all kind of public goods funded by taxes. The state fosters innovation (for example by funding research and development) (Chang 2010, 206), ${ }^{6}$ encourages investment, promotes economic growth, boosts worker productivity and stimulates the efficient use of scarce resources. All these policy goals are funded by taxes; thus, paid by society, or rather by those members of society that pay their share of taxes.

As stated above, the central question of morality is how one should live in relation to other individuals and society at large (§2). Individuals, natural persons, are clearly to be seen as moral agents. But what about corporations? Are corporations extensions of their members or rather moral agents in their own right? Are they independent entities and therefore morally accountable for their tax planning, or is it only possible to hold the individuals involved in a company morally accountable? Can corporations be morally responsible for their actions, such as their tax planning practices? This is the issue of corporate moral agency.

To our minds, the corporations qualify as moral agents, for morality does not regard only individuals. Naturally, the corporations are entities that are different from natural persons. Nevertheless, it makes sense to treat the corporations as moral agents, because they "have their own decision making structures, have choices, and justify them with corporate reasons" (Brown 2005, 123). Companies as such can therefore refrain from harming others and they can account for their behavior by giving moral reasons and assume moral responsibility for their actions affecting others. They are not only legal entities (i.e., artificial persons at law), but also moral ones (i.e., they have agency independent of their members).

As Paine argues, morality is as much an organizational as a personal issue: "organizations shape individuals' behavior" (Paine 1994, 107). Corporations have an in-

\footnotetext{
6 This goes even for countries which seemingly do not feature that much government intervention. See, for example, Chang (2010, 206): "Between the 1950s and 1980s [...] the share of government funding in total R\&D in the supposedly free-market US accounting for, depending on the year, between 47 per cent and 65 per cent, as against around 20 per cent in Japan and Korea.”
}

ternal decision making framework which results in decisions that cannot directly be traced back to individual actors. By way of decision making structures, corporations establish an explicit or implicit purpose for decisions that "clearly transcends the individual's framework for decisions" (Crane and Matten 2007, 45). Corporations make decisions of their own, to be distinguished from decisions made by individuals involved in the corporations. Moreover, the presence of organizational norms and an organizational culture, which delineates acceptable standards of behavior, are a key feature of companies. The organizational culture consists of a set of shared values, meanings, beliefs and behaviors setting out what is generally regarded as right or wrong within the company. Organizational culture influences the ethical decision making and behavior of individual members. It has been "widely identified as a key issue in shaping ethical decision making" (Crane and Matten 2007, 159).

Internal decision making structures and organizational culture thus account for the fact that the moral decisions of individuals within a corporation may differ from those taken by an individual outside that corporation. As with individuals, the moral point of view requires not that companies consider only the interests of others, but rather that companies see their corporate interests and objectives in relation to those of others. Again, acting in a morally appropriate way is often a matter of balancing competing interests, principles, values and ideals. This commitment to principled thinking should be consistent and not opportunistic; it must permeate all the company's actions.

Thus, corporations have a kind of moral responsibility that differs from the responsibility of individuals constituting the corporation. This moral agency is clearly evidenced by companies engaging in corporate social responsibility, for they accept the ethical responsibilities vis-à-vis the society (see §7). This is a way of taking the responsibilities of businesses towards society seriously. One's view on CSR of course depends on one's view of the corporation. CSR companies do not seem to be like the neoliberal free market thinkers, who advocate that corporations have the obligation to maximize profits and maximize shareholders' value, nothing more. Milton Friedman, the famous proponent of this libertarian economic philosophy, is indeed often said to defend a position like this. However, he argued for the maximization of profits "while conforming to the basic rules of the society, both those embodied in law and those embodied in ethical custom" (Friedman 1970, 32-33). Thus, he can be understood as supporting a thin theory of CSR (Schwartz 2011, 56). Moreover, Friedman's libertarian economic approach might even be compatible with a different, richer conception of the moral responsibility of 
corporations (Machan 1999; he spells out a position called "classical individualism"). Thus, on second thought, even some free market thinkers may support some kind of CSR - though to a limited extent. Moreover, Friedman's view that the manager is an agent of the owners implicitly supports the CSR legislation, for "curiously, agency costs appear to be lowest in the case where governments obligate CSR activity by the firm" (Salazar and Husted 2008, 150; they refer to CSR legislation as being proposed in different countries, such as Spain). This implicit support for legislation might seem to be a bit of a paradox for proponents of the free market, such as Friedman, who after all do not favor government intervention.

We defend a thicker conception of the moral responsibility of corporations. It is submitted that the corporation is comparable to an individual in its moral rights and obligations. Like an individual a corporation should behave responsibility vis-à-vis other members of society. This view is comparable to the "real entity" view as discussed by AviYonah: "Under the real entity view, the corporation is similar to an individual citizen in its rights and obligations." $\mathrm{He}$ goes on to maintain that individual citizens and corporations alike do not have a legal requirement to aid their fellow members of the society but they are praised if they do so. Thus, "the corporation may not be required to engage in CSR, but corporate management should be encouraged if they do so" (Avi-Yonah 2014, 10).

In the foregoing, it was implicitly assumed that taxation has a moral dimension. The moral requirement of acting in a responsible way being established, we can now turn to this issue. How does tax planning relate to morality?

\section{Tax Planning}

Tax planning, tax avoidance and tax evasion are different ways in which businesses respond to tax legislation. In order to remain in control of their finances, individuals and corporations have to know the impact of taxation and tune their behavior to this impact. Thus, they engage in tax planning. In an international context, tax planning is often used to avoid double taxation (Gribnau 2015, 239240). For the purpose of this article, tax planning should be understood in a neutral ethical way, as opposed to, for example, tax evasion and tax avoidance, which often have a negative - unethical - overtone. The conventional (legal) distinction between tax evasion and tax avoidance seems to be quite clear. The former is illegal; the latter is legal. Taken in its broadest sense, the concept of tax avoid- ance comprises "all arrangements to reduce, eliminate or defer a tax liability” (Freedman 2014, 336). The term "aggressive tax planning”, in a way, moves away from this legal distinction between tax evasion and tax avoidance. According to the European Commission, aggressive tax planning consists of taking advantage of the technicalities of a tax system or of mismatches between two or more tax systems for the purpose of reducing the tax liability (European Commission 2012, 2). This downward management of taxable income through tax planning activities results in paying little or no tax; it reflects a calculating, minimalist compliance with the law.

With this distinction in mind, quite a few (corporate) taxpayers and their tax consultants are willing to contend that gaming the system (for example by using tax shelters $)^{7}$ can be classified as playing by the rules. What is meant by such a statement is that their game is a strictly legal one, and playing by the rules is playing by the legal rules. It is all about the letter of the law - stripped to the bone by gaming the (international) rules. The issue of aggressive tax planning lies exactly in complying with the letter of the law, for example by making use of mismatches (disparities) between various national tax systems, which then are creatively used by multinationals to pay less tax. McBarnet $(2007,48)$ calls it creative compliance with the law. This kind of tax planning remains within the boundary of the letter of the law (of different jurisdictions), but nonetheless it is often questioned - for example, by NGOs and consumers - whether the multinationals pay their fair share (see \$1).

Discussions regarding the concept of fair share seem to be endless and complex, and it is not the aim of this article to delve deeper into this topic. At the moment, there is no one uniform understanding of what is the fair amount of taxes to be paid. Nonetheless, ethical companies should be aware that it might be that paying a fair share is not always the same as paying according to the letter of the tax

7 See, for example, Hanlon and Slemrod 2009, 126-127. See their footnote 4: “The term 'tax shelter' has no universally accepted definition, and can be used in a variety of ways depending on the context. Our use of the term refers to complex transactions used by corporations to obtain significant tax benefits probably never intended by the tax code; these transactions may not be illegal per se and their use, if detected, may trigger lengthy processes of IRS assessment and judicial appeal. Our empirical analysis refers to press uses of this term, and therefore, relates to the interpretation given by the press outlets themselves." The appendix to their article also contains a description of the shelters included in their sample. Also see Braithwaite 2005, 16: "What Australians refer to as the market for aggressive tax planning, Americans refer to as the market for tax shelters." 
law. Paying (almost) no tax at all in countries where corporations operate and make use of public goods and services is in any case not a "fair share". Responsible companies should be willing to pay a fair share of tax and reflect on the moral quality of their tax planning strategy and practice. They should, thus, account for their tax behavior. Companies willing to engage in responsible tax governance need to be transparent about their tax strategy and discuss it with their stakeholders (see $\S 8$ ).

We will give an example of corporate tax planning. Just as most corporate income tax laws worldwide, the Netherlands' corporate income tax law treats interest and dividend payments differently, by allowing interest expenses as taxable deduction while disallowing dividend payments. Usually businesses, including all multinational enterprises, are organized as a group of legal entities, with a parent company (head office) and subsidiaries. The legal structure makes it possible to finance each subsidiary company with as much debt or equity as the group may deem appropriate. From a group perspective, the tax factor shall often be decisive in this financing decision, as the overall leverage on group level is not affected by the intra-group financing structure. ${ }^{8}$ Tax-wise, a benefit can be obtained by financing high-taxed subsidiaries with debt and lowtaxed subsidiaries with equity. It is this mechanism that has led most jurisdictions, in any case the high-tax jurisdictions, to put some limitation on interest deductions to protect the domestic corporate tax base. A not too complicated rule, tax deductibility of interest, thus creates a good deal of tax planning.

Tax planning can however become more aggressive as exemplified by the phenomenon of "stateless income". Kleinbard describes it "as income derived for tax purposes by a multinational group from business activities in a country other than the domicile of the group's ultimate parent company but which is subject to tax only in a jurisdiction that is neither the source of the factors of production through which the income was derived, nor the domicile of the group's parent company" (Kleinbard 2013, 1517-1518). Starbucks and other multinational corporations have made stateless income planning into a widespread problem (Van den Hurk 2014). Tax avoidance or aggressive tax planning, both of which remain within the letter of the law, have created complicated discussions when such activities are exercised in an international context. The problem, namely, is not always the question as to whether

8 Of course, there may be commercial reasons influencing the debtto-equity ratio as well, such as currency restrictions, or external financing at subgroup level. multinationals act legally or not, but rather whether they cross some kind of accepted (moral) line. It has become clear that this legal understanding of creative compliance does not exactly correspond with the public's understanding of playing by the rules. Taxpayers should therefore be aware that there is a gap between the idea of playing by the rules and gaming the legal rules. Their tax planning strategies should take into account the difference between a strictly legal understanding and the moral understanding that drives the public outcry over aggressive tax planning practices. Aggressive tax planning, which boils down to gaming the system as much as possible, is labelled as "aggressive" because it is perceived as unfair. Moreover, justifying such calculating minimalist compliance with the law as playing by the rules, may even be perceived as hypocrisy by some (see for example Browning 2007).

However, not all tax planning should be seen as morally unacceptable. Businesses may, for instance, have a low effective tax rate because they make use of tax incentives (e.g., for R\&D). Tax incentives are used to achieve all kinds of economic, social and cultural policy goals. In times of financial crisis, for example, businesses benefit from tax incentives, such as accelerated depreciation. Tax incentives are used to affect the taxpayers' behavior, and are a stimuli for the taxpayers to engage in tax planning practices that will result in a lower tax burden. Consequently, tax planning in order to make legitimate use of tax incentives cannot easily be labelled as "aggressive". Moreover, states should be aware that steering the taxpayers' behavior by way of tax incentives stimulates them to adopt a calculating attitude towards the tax system. It breeds a rule-based mindset focused on tax planning. At some point, the widespread use of tax incentives - to achieve a host of policy goals - may crowd out ethics. The dominance of an economic-rational perspective may replace important legal-ethical principles in the taxpayer decision-making process. ${ }^{9}$ Sometimes (the implementation of) tax legislation incentivizes the use of devices that are highly artificial - "encouraging a culture of tax avoidance" (Freedman 2006, 371). Thus, the intrinsic, moral motives of taxpayers to comply could be crowded out by excessive, complex and unbalanced legislation.

As stated, taxes are contributions to the society. They enable this "cooperative venture" and embody the distribution of the (financial) burden this societal cooperation

9 Moreover, the fairness of the tax system - the fairness of the distribution of the tax burden - becomes less transparent. The idea of distributive justice is thwarted because of - often very legitimate policy concerns. See also Gribnau 2015, 233-234. 
entails. Hence, morality is inherent in taxation (see §2). The moral aspect of taxes does not do away with the simple fact that taxes are also an expense. Taxpayers may arrange their tax affairs as they wish. Both individuals and businesses may plan and structure their affairs to achieve a favorable tax treatment within the limits set by the law. In many jurisdictions, this is a settled case law. ${ }^{10}$ Taking tax considerations into account is perfectly legitimate for natural persons and enterprises, alike. The general public should be well aware of this right and the actual exercise thereof in practice. Most people facing a choice involving paying more or less taxes, for example, when arranging a mortgage, opt for a tax-efficient course of action. However, the public outcry does not concern companies achieving a "legitimate" favorable or tax-efficient tax burden, but rather those multinationals that are perceived as paying hardly any (corporate income) taxes at all. The latter goes at the expense of public revenue in times of austerity and shifting the tax burden to less expert taxpayers (level playing field). They do not exactly balance their selfinterest with those of other individuals. That makes such tax avoiding multinationals free-riders.

In our opinion, the corporate taxpayers who want to show moral leadership should balance their right to structure their affairs to achieve a favorable tax treatment within the limits set by the law with the obligation to accept the inevitable imperfections of the legal system. Thus, they should not abuse the letter of the law for their own good at the expense of society. Just like individual citizens, corporations are legally required to pay taxes, and are expected not to engage in over-aggressive tax planning to minimize their tax obligations (Avi-Yonah 2014, 10). Taxpayers should therefore impose restraints on themselves in taking advantage of these inevitable and often unintended imperfections. Tax avoidance, though legal, may result in free riding, entailing a breach of the duty of fair play. Society as a cooperative venture implies a duty of fair play for the individuals accepting the benefits which social cooperation provides. Corporate citizens who evidently do not pay any fair share of taxes at all, evade the duty of fair play. Corporate citizens neglecting this duty violate the principles of responsibility and reciprocity (Gribnau 2017a). The corporations that fail to meet the values and moral expectations of society might bear costs for that. Such costs of tax avoidance can occur in the form of reputation damage. Therefore, we now investigate whether

10 Cf. European Court of Justice, 21 Feb. 2006, Case C-255/02, Halifax plc and others v. Commissioners of Customs \& Excise, [2006] ECR I-1609, para. 73. there is a relationship between negative publicity about a multinational enterprise's being involved in tax avoidance and its corporate reputation.

\section{Tax planning, trust and reputation}

Reputation matters because it "inform us about what products to buy, what companies to work for, or what stocks to invest in" (Fombrun 1996, 5). Corporate reputation is according to Ivey a "dynamic, multi-dimensional concept built on the perceptions of past behavior and a reflection of future expectations" (Ivey 2010, 337). She goes on to argue that people use knowledge of a corporation's past behavior to gauge its future behavior: the "more trust we have in a corporation, or person, the more certain we are of our expectations." Reputation, thus, reflects trust.

In 2012, Starbucks, for example, seemed to be well aware that its aggressive tax planning practice was the cause of diminished trust in the UK. Starbucks' tax planning strategy was considered too aggressive and it was met with extensive negative publicity, a "naming and shaming" campaign of NGOs and a customer strike. Stakeholders' behavior showed that Starbucks's reputation was quite vulnerable and it therefore decided to address the cause of this negative corporate image quickly (see also Gribnau et al. 2016). Starbucks decided to restore the trust by showing a change in its tax practice (Engskov 2012a,b). Kris Engskov, director of the Starbucks UK, stated that while Starbucks has always paid taxes "to the letter of the law", they acknowledge that to retain public trust they need to do more. In his letter (16 October 2012) Engskov also noted that Starbucks is "doing business to the highest ethical standards" both in sourcing coffee as well as in paying taxes (Engskov 2012a). Later (6 December 2012) he added that "the most important asset" Starbucks has built "in the UK is trust - trust with our employees, customers and the wider society in which we operate" (Engskov 2012b). He further added that "it is vital to listen closely to our customers - and that acting responsibly makes good business sense" (Engskov 2012b). Based on such statements, we can assume that the multinational was negatively affected by negative reputation following the publicity of its tax planning practices. The Starbucks case shows that tax avoidance could be one of the factors that can diminish trust and, therefore, also negatively affect the corporate reputation. According to YouGov research, Starbucks suffered severe reputational damages after the HMRC hearings in 2012 - even more severe than 
Amazon and Google whose tax planning practices were also covered by the HMRC public hearing (2012) as well as media (YouGov 2012, 2014).

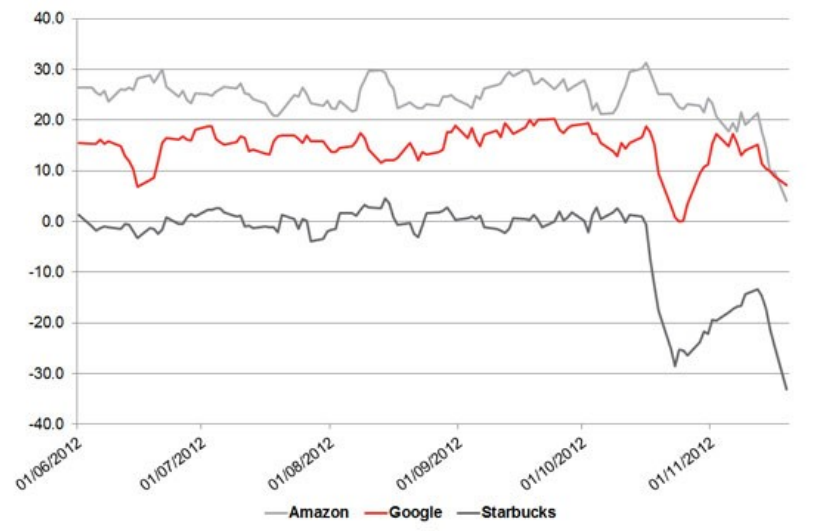

Figure 1: Change in Corporate Reputations

Source: YouGov 2012.

The Starbucks case thus shows that corporate reputation, trust and ethical behavior are closely connected. Multinationals, such as Starbucks, are especially sensitive to reputation damage. The research of Crane and others shows that large corporations are much more visible and thus more vulnerable to criticism from the public than smaller firms (Crane et al. 2008, 8-9). Moreover, the way the general public perceives business' role in a society has changed in the last few decades.

Lewis researched the public's attitude towards large companies between the late 1970s and early 2000s. He found that approximately $80 \%$ of the respondents believe that large companies have a moral duty to society. Nevertheless, according to the same respondents (about 60\%) large corporations fall short of the expectations for moral behavior towards society and environment. As a result, the corporations are losing public trust (Lewis 2003; see also Porter 2003; Wan-Jan 2006), which in turn may have a negative impact on their reputation. But what exactly is corporate reputation?

Corporate reputation can be seen as "an overall assessment of an organization by its stakeholders" (Gribnau et al. 2016). Lange and others characterize organizational reputation "by a level of familiarity with the organization, beliefs about what to expect from the organization in the future, and impressions about the organization's overall appeal" (Lange et al. 2011, 178). Thus, to understand the importance of reputation is to recognize "the social world" that helps a company to succeed, for a company "works" in the center of a network of cooperating stakeholders (Fom- brun 1996, 21). A reputation is the result of judgments in moral terms for it is "the aggregate of many personal judgments about the company's credibility, reliability, responsibility, and trustworthiness" (Fombrun 1996, 72). Thus, corporate reputation entails a "value judgement" (Gray and Balmer 1998, 679), for stakeholders take values into account when evaluating a corporation's behavior. Taking these values seriously reflects a corporation's commitment to "others with whom we interact personally, as well as those more distant who may be affected by what we do" (Paine 1996, 478). Dealing with these values in a responsible way enhances the community's acceptance of a corporation's behavior. Corporate reputation is thus "related to the acceptance of the community where a company is operating” (Melé 2008, 49; see also Lewis 2003). Therefore, in order to have a social license to operate from the society, multinationals need to show that they respect the social morals and values. Thus, they need to show that by contributing to the public goods and services by paying taxes they are not free-riders.

Hence, "purely legal boundaries of the firm are no longer a safe haven" (Davis et al. 2006, 19). Respect for ethical values is linked to trust. According to the literature, reputation is a result of trustworthy behavior (Swift 2001; see also Jøsang et al. 2007, Eisenegger 2009, 11-12). Trust is a fundament of every relationship - both business and non-business (Perrini et al. 2010, 195). Therefore, trust is an important asset when addressing ethical issues in business and building a reputation of a good corporation. Castaldo and others argue that trust "provides the cultural basis and the 'glue' that promote ethical behavior, and discourages deviation from ethical norms" (Castaldo et al. 2010, 657). Therefore, corporations that are trusted are believed to make moral decisions, and the other way around - corporations that make moral decisions are trusted (see also Jallai 2017). In short, companies that make moral decisions and are therefore trusted, also have a better reputation. This was also shown in the Starbucks' case discussed above. But what should we make of moral decision making with regard to legal obligations; especially in the context of tax planning?

As stated, ethical behavior may entail going beyond what is required by (the letter of) the law. In the same vein, the G20/OECD Principles of Corporate Governance (2015b, 34) state that "even in areas where stakeholder interests are not legislated, many firms make additional commitments to stakeholders, and concern over corporate reputation and corporate performance often requires the recognition of broader interests." Ethical behavior that goes beyond what the law demands enhances the trust of stakeholders and society at large. "High ethical standards are 
in the long term interests of the company as a means to make it credible and trustworthy, not only in day-to-day operations but also with respect to longer term commitments" (OECD 2015b, 47). Businesses going beyond what is required by the law thus show awareness of the public demand to go beyond the morality that is codified in the legal system. They may be driven by intrinsic motivation to behave ethically. Voluntary commitments by companies to go beyond minimalist compliance with the letter of law may also include tax planning strategies, for according to these G20/OECD Principles (2015b, 47) “aggressive tax avoidance" does not fit in an "overall framework for ethical conduct [that] goes beyond compliance with the law, which should always be a fundamental requirement." Ethical behavior entailing going beyond the letter of the tax law is also one of the crucial elements of a CSR-policy, as will be shown in the following section.

CSR can play an important role in building "competitive advantage by enhancing the reputation and legitimacy of the organization” (Kurucz et al. 2008, 90-91). For a corporation like Starbucks, which is in the eye of the storm and fundamentally believes that it should act responsibly, CSR could be a tool to (re-)build this trust and thereby also corporations' competitive position (Lewis 2003, Porter 2003, Wan-Jan 2006, 180). CSR can thus be considered as a means to build better corporate reputation (Wan-Jan 2006, 180). Therefore, we believe that corporations should employ CSR to build better tax morale and thereby also better reputation. Moreover, corporations that already endorse CSR should be more responsible and transparent in their tax matters in order to (re)gain their stakeholders' trust, as some multinationals have tried. In the next section, we will elaborate on this point of view.

\section{Companies that Play Fair}

The foregoing shows that a company's (aggressive) tax planning strategy may have consequences in terms of reputational costs that can be related to the loss of public trust in companies. As argued above ( $\$ 2$ and $\S 5$ ), there is more to taxation than the financial aspect, for taxes are a contribution to the society, which in turn involves morality, and thus paying taxes entails a moral choice. This raises the question concerning how can companies take into account both the aspects of taxes.

Companies that acknowledge (moral) obligations towards society can opt to implement social responsibility policies (we further call them CSR companies). CSR in relation to law is a business strategy that reflects the areas in which the company (aims to) step beyond pure compliance with the letter of the law (McBarnet 2007, 48-50). CSR can have many different definitions depending on the context and subject from which the viewpoint definition comes. ${ }^{11}$ For instance, both the EU (European Commission CSR) and the OECD (CSR) have contributed attention to the social responsibilities of corporations. According to the European Commission, CSR "refers to companies voluntarily going beyond what the law requires to achieve social and environmental objectives during the course of their daily business activities" (European Commission CSR). The OECD (CSR FAQ) refers to "the mutual dependence of business and society" where "corporate responsibility" concerns the corporate role in this relationship. The OECD also states that "the core element of corporate responsibility concerns business activity itself" and adds that "corporate responsibility goes beyond the core function of conducting business" (OECD CSR FAQ). Moreover, the OECD expects that businesses comply next to the written laws also with the "societal expectations that are not written down as formal law" (OECD CSR FAQ). These elements of the OECD and EU definitions give some general indication as to what these regulators expect from CSR. They both signal the significance of (voluntarily) moving beyond pure compliance with the law.

In order to understand the essence of such moving beyond the letter of the law and complying with the societal expectations and values, we turn to CSR theory. Carroll, one of the most influential authors in this field, has developed a CSR Pyramid that describes four building blocks of CSR: economic, legal, ethical and philanthropic responsibilities (Carroll 1991).

According to Carroll (1991), corporations are a part of the "social contract" and are therefore expected to pursue their economic missions within the framework of the law. Moreover, above the economic and legal layers, Carroll sees the ethical and philanthropic layers. Ethical responsibilities of a company go beyond the law and profit making, and embody those standards, norms or expectations that reflect a concern for what consumers, employees, shareholders and the community regard as fair, just or moral. He adds that it is expected that ethical responsibilities - which are seen as the obligation to do what is right, just and fair - are fulfilled (Carroll 1991, 42). Ethical considerations go beyond compliance with the law. The philanthropic layer of Carroll encompasses those cor-

11 For an overview of the term "corporate social responsibility", see Carroll 2008, 19; Benn and Bolton 2011, 56-63; Carroll 1999, 268; Williams and Aguilera 2008, 452; Dahlsrud 2008. 
The Pyramid of Corporate Social Responsibility

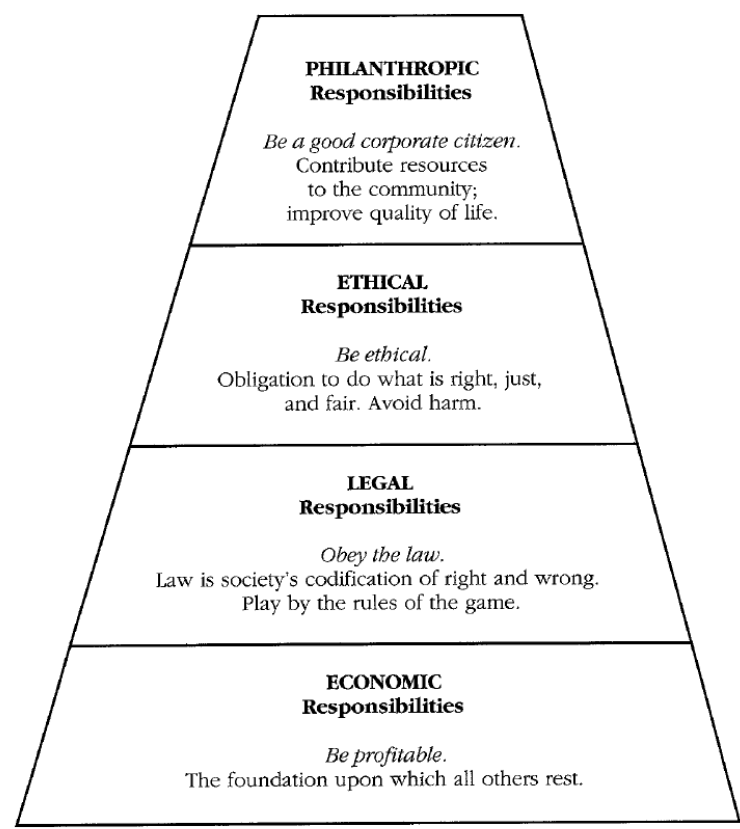

Figure 2: CSR Pyramid

Source: Carroll 1991, 42.

porate actions that are in response to the society's expectations of a good corporate citizen, for example, actively engaging in activities or programmes to promote human welfare or goodwill (Carroll 1991). Although Carroll's CSR theory has been substantially revised (Schwartz and Carroll 2003), the core elements of importance for the present article remain the same. The purpose of this article is to illustrate the general picture of CSR and not the mutual relations among the building blocks, as specified in Carroll and Schwartz's definition (Schwartz and Carroll 2003). Therefore, we use the Pyramid theory.

Naturally, there are also other authors who have contributed to the conceptualization of CSR (see, e.g., Wood 1991; Frederick 1994). However, Carroll's theory (with its core ethical considerations as "beyond compliance") fits well with the nature of tax planning. Thus, the distinction between different kinds of obligations is very useful with regard to (aggressive) tax planning, as will be shown. Moreover, Carroll's theory reflecting on social contract and moral values also fits in with the view of Paine who argued that the morality involves how we act in a society in relation to others (see §2 - §4).

CSR and ethical business making as such are already on the agendas of many corporations, but also of law and policy framing institutions. For example, since the introduction of EU Directive 2006/46/EC (2006), all the listed companies in the European Union are obliged to pub- lish their CSR statements. What such statements exactly should entail is unclear. Therefore, the question still remains as to whether these published strategies can also be regarded as acting socially responsible.

In our opinion, a corporation engaging in CSR can be driven by two different motives: intrinsic and extrinsic motives. ${ }^{12}$ Intrinsic motives are a characteristic of an integritybased approach. Morality drives the company, although of course economic performance (profits) and compliance with the law are relevant factors. Integrity is based on the concept of self-governance "in accordance with a set of guiding principles" (Paine 1994, 111). The intrinsic motivation is directly connected to morality, to an internal drive to do what is right, just and fair. The extrinsic motivation, on the other hand, indicates that a corporation behaves in a certain way because of some (external) reward, coercion or a desire to avoid penalties or bad press. Extrinsic motivation is, therefore, a feature of an instrumentalist morality; the societal acceptance of a company's ethical behavior is exclusively measured by the lack of public resistance. Here, the "status" or "good reputation" is a matter of public relations and is thus not guided by an intrinsic drive to be open and transparent (Ulrich 2008, 400). Thus, intrinsic motivation is driven by moral principles while extrinsic motivation is driven by self-interest. However, communicative transparency that is a matter of extrinsic motivation is not a matter of principle.

When an extrinsic motivation prevails, the firm's responsible behavior is not driven by an internal wish to do what is right, just and fair. Without an intrinsic motivation, a CSR approach is seen as an instrument to purely enhance the firm's reputation (which, in turn, will often be an instrument to achieve something else, for example an increase in market value) (Freedman 2006, 384), and not as a by-product of responsible behavior (Benn and Bolton 2011, 57-58). ${ }^{13}$ Thus, CSR actions can be attributed to both intrinsic and extrinsic motives (Du et al. 2007, 226). For a business, it is probably easier to motivate its actions from an extrinsic perspective, because usually in a business context, the cost-benefit analysis prevails. Nevertheless, in order to be a true moral leader in the market, CSR should be initiated from an intrinsic perspective. That is because the corporations that are driven by an extrinsic motivation do

12 Compare the view of CSR as a moral obligation towards society and stakeholders in contradistinction with the view of CSR as a pure marketing tool, for example, Salazar and Husted 2008, 147-150; Garriga and Melé 2004, 51; Benn and Bolton 2011, 14-17, 56-62, 112-113, 115118.

13 This may also be labelled as "passive tax responsibility" versus “active tax responsibility". See, for example, Cerioni 2014, 851-852. 
not reach above the legal layer of Carroll's pyramid as their motivation serves economic goals within the (letter of the) law. But how can corporations show an intrinsic (good) intention with regard to taxation and thereby become moral leaders in this respect?

\section{Tax Planning and Corporate Social Responsibility}

The above discussion proves that corporations have to deal with the moral and societal choices when planning taxes. According to Ruggie, "social norms exist over and above compliance with laws and regulations" (Ruggie 2013, 91). Therefore, businesses are not free to do as they wish to increase their income, market share or alike. Corporations minimizing their tax liability behave irresponsibly in the eyes of the public - at least as long as they use their corporate power for law avoidance to create various tax structures (Jallai 2017). The fact that taxes are moral phenomena places them also at the heart of the notion of CSR. This commitment to CSR should be consistently applied to all the company's dealings and activities. Nevertheless, in practice, the link between tax planning and CSR is not all that clear yet. Therefore, we will have a closer look at the question as to how companies can show that they are behaving in a morally responsible way when it comes to tax planning.

Despite the unclear concept of fair share (see §5), many people believe that multinationals tend not to pay their fair share (see, e.g., Happé 2007, Happé 2015, UK HMRC 2012). In order to establish the actual meaning of this concept in tax practice and the elbow room it leaves to multinationals, public debate is necessary. Socially responsible companies should, therefore, be willing to discuss their tax planning, which demands certain openness on their part. Having said that, one could distinguish a substantive approach and a procedural approach to integrate tax planning into the CSR agenda. A substantive approach focuses on the amount of tax that a company pays, and asks whether this is more than is demanded by mere compliance with the letter of the law (stripped to the bone by gaming the rules; $§ 5$ ). A procedural approach provides information on a company's tax strategy, for instance on how much corporate income tax it pays in all the countries it operates in. Here, transparency is key (Gutmann 2010, 546-547). Thus, a key element of Carroll's CSR theory, the idea of "going beyond compliance" can be defined in two layers:
- substantive good tax governance: taking into account the spirit of the law, or at least not stretching the letter of the law for paying nil corporate income tax in countries where the company operates; and

- procedural good tax governance: transparency, going beyond compliance with legal disclosure requirements and reporting obligations.

Both layers, substantial and procedural, are a part of CSR. Furthermore, they interact, as will be explained. Transparency can be viewed as a door to corporate accountability. In other words, a dialogue between a corporation and its stakeholders demands transparency. Naturally, the authors of this article acknowledge that "transparency" is a broad and complicated concept (see, e.g., Schnackenberg and Tomlinson 2016). For the purposes of this article, transparency is considered as a principle of being open about one's tax planning practices. As transparency in corporate tax matters reflects an ethical value, we conceptualize it as a principle. Conceptualizing transparency as a principle accounts for intrinsic motivation and thus moral considerations which drive a socially responsible company.

In practice, regulatory attempts to tie tax and ethics (or at least better governance), such as the OECD BEPS Action Plan (OECD BEPS), the EU Action Plan (European Commission 2016a), but also VBDO Good Tax Governance standards, and ISO 26000 standards, have been undertaken. The focus of all these lies on transparency. The European Commission, for instance, states that "transparency is a crucial element in securing fairer taxation", adding that the Commission has "given high priority to improving tax transparency in the Single Market” (European Commission 2015a, see also European Commission 2015b, European Commission 2016a).

One of the reasons why various international regulatory approaches aim to create more transparency in tax planning discussions is to minimize information asymmetry. The latter is a term that is widely used in economics to describe situations in which one party to a transaction or agreement has less information than the other (see, e.g., Stiglitz 2002, 469-470). In tax matters, information asymmetry paves the way, for example, for fair-share discussions. An illustration of a regulatory attempt to minimize information asymmetry could be, for example, the European Commission which "promotes the three principles of good tax governance - namely transparency, exchange of information and fair tax competition - in relations between states" (European Commission 2011). Enterprises are also encouraged, where appropriate, to work towards the implementation of these principles. The EU is fight- 
ing against tax avoidance with its action plan for fair corporate taxation in the EU. ${ }^{14}$ The policy in the EU focuses among others on transparency between the member states in order to eliminate information and knowledge gaps (European Commission 2015b). Amongst other measures, the EU has introduced the country-by-country reporting between Member States' tax authorities to enhance transparency (Administrative Cooperation Directive). Also, the OECD has developed a country-by-country reporting ( $\mathrm{CbC}$ reporting) measure as developed under Action 13 of the BEPS Action Plan (OECD BEPS). The aim of $\mathrm{CbC}$ reporting is to increase transparency towards tax authorities for tackling aggressive tax planning issues (OECD 2015a). CbC reporting encompasses a three-tiered approach to transfer pricing documentation that should consist of a master file, a local file and a $\mathrm{CbC}$ report. Moreover, there is a proposal for public $\mathrm{CbC}$ reporting to enhance public scrutiny of corporate income taxes borne by multinationals which will 'further foster corporate responsibility' (European Commission 2016b, 9). ${ }^{15}$ However, these regulatory measures have also earned some criticism (see, e.g., Cockfield and MacArthur 2015; Nouwen 2017). Nevertheless, a consideration of whether this specific form of regulatory transparency works is beyond the scope of this article.

However, a noteworthy question for this article is whether and what kind of relationship there is between corporate transparency and aggressive tax planning. Existing research suggests that corporate transparency and aggressive tax planning are negatively correlated (Balakrishnan et al. 2012). Therefore, by communicating openly about their strategies, companies have the possibility to substantiate their belief that they act in a morally sound way. This, in turn, may be a proof of an intrinsic motivation to endorse CSR. Thus, the first step towards showing an intrinsic motive in relation to taxation is transparency. When a corporation is convinced that its tax planning practices are legal and legitimate (responsible), it should be able to report this openly to the public. If a corporation does feel the need to hide something, it should be seen as a red flag. Naturally, the use and translation of this information for the wider public should be handled in a fair and educated way by the receiver (such as media and politicians, for instance). We, however, focus on the corporate perspective.

14 See European Commission's Agenda for the Fair Corporate Taxation in the EU information chart: http://ec.europa.eu/taxat ion_customs/sites/taxation/files/resources/documents/taxation/com pany_tax/anti_tax_avoidance/timeline_without_logo.png. Accessed 02 March 2017.

15 For more detailed discussion of CbC Reporting, see OECD 2015a and European Commission 2016b.

\section{Good tax governance}

Transparency is one of the key principles of CSR (see, e.g., ISO 2010, 14). Therefore, companies that engage in CSR should also be transparent about their tax practices. But how could these tax practices live up to the concept of CSR? Naturally, the above-explained CSR Pyramid of Carroll is not a perfect theory, but it does indicate some lines to follow for a company that drives to be a good corporate citizen. Looking at Carroll's Pyramid, the fundamental blocks for a company are economic and legal responsibilities. In the context of tax, one can translate it in a way that corporations first have to plan their taxes and thereby reasonably lower their (tax) costs, the economic layer. Moreover, companies must plan their taxes within the framework of the law - the legal layer. Taken together these two layers account for the fact that companies have the legal right to structure their affairs in a tax favorable way. When moving further in the pyramid, the ethical layer reflects the substantive part of good tax governance.

The easiest way to use this Pyramid as a practical guide is to think that everything that does not fit in the pyramid should not be done. Moreover, everything that does not fit in the economic, legal and ethical layer should not be done by a CSR company that wants to show moral leadership in tax matters. Naturally, to which extent a corporation should consider other responsibilities in addition to economic and legal ones, is an area that needs more research. One thing is, nevertheless, certain: for CSR companies, there are also ethical considerations in addition to legal and economic ones when defining and implementing a business strategy and making decisions. Multinationals that claim to be CSR companies should not engage in fiscal engineering in order to pay (almost) no corporate income taxes in the societies in which they operate.

CSR might not be a quick solution to diminish aggressive tax planning practices, but it does open a door for discussion in order to establish what are legitimate or acceptable tax planning practices. Transparency and openness, from the perspective of corporations, are a precondition for a focused discussion, for it is necessary to get the facts right and take on board different perspectives. This, in turn, helps corporations to protect (or where necessary to re-establish) or advance their reputation. Furthermore, transparency and the inclusion of tax in CSR reporting would help to minimize the information asymmetry gap that, in current debates, seems to confuse the understanding of the problem. One of the most significant procedural elements of CSR is reporting and openness (see, e.g., McBarnet 2007, 32-37; GRI Sustainability Report- 
ing). Transparency is never an end in itself; it is always a means to some other value, for example accountability. In any case, transparency and openness are the first steps towards moral tax behavior. Moreover, transparency is a precondition for accountability and open debate, which is also crucial in creating a better tax compliance environment. A debate promotes a better understanding of factors that businesses take into account in their tax decisions and the moral acceptability of tax planning practices. A fruitful debate is indispensable for developing standards of substantive good tax governance.

It is important to note that in order to show moral awareness that is advocated in this article, companies should publish relevant information concerning their tax planning practices, rather than simply publishing as much (confusing) information as possible (which might be perceived as self-serving hypocrisy). Communication of relevant information is the key to an open moral debate. What matters is the quality, and not the quantity, of information. Corporations should not communicate only about what they do, but also why they do certain things. Multinationals should be open about their motives in order to contribute to a fruitful and much needed discussion. Companies themselves need such discussion as well since they also need to understand what is accepted by the societies in which they operate and what could cause possible reputational damage. Naturally, transparency and openness should not be confused with an obligation to publish sensitive business information that may harm a company's competitive position. Conceptualizing transparency as a principle means that there may be other principles which act as a counterargument and may thus carry more weight (Gribnau 2014). This may lead, for example, to a decision to partially publish certain information. The idea behind transparency, as discussed in this article, is that third parties would understand a firm's tax policy (e.g., why it takes certain tax decisions and which intentions are driving those decisions).

Transparency in tax matters can thus be seen as a bridge for connecting tax and CSR. Transparency, however, should be seen as a first step towards finding a solution to aggressive tax planning, rather than a solution in itself. It is a necessary precondition for an informed public debate. In this way, transparency may have an educative function. As Stevens notes, transparency "will force all stakeholders in a tax system to answer difficult moral and justification questions about how that system works and the foundations on which it is based" (Stevens 2014, 708). More transparency, as mentioned, would decrease the existing information asymmetry. As such, it may accelerate and sharpen the necessary discussions around fair share and tax morale, and contribute to changing the mind-set surrounding aggressive tax planning. In order to change the situation, companies need to change the mind-set and start viewing tax as an element of doing good and behaving just.

\section{Irresponsible tax planning versus good tax governance}

It goes without saying that there is also criticism on viewing taxation in the context of CSR. Some scholars, for instance Van der Geld (2006), seem to argue that almost all responsibility lies with the legislature. To his mind, the legislature enacts all too often sloppy tax laws and the taxpayers have a right to take advantage of the sloppy tax legislation (Van der Geld 2006). Moreover, aggressive tax planning, like stateless income planning, is sometimes perceived as the result of (harmful) tax competition between nations (Panayi 2015, 445). This argument seems to imply that all the responsibility lies with states and there is no need for any moral reflection by taxpayers. This line of thinking is often thought to be reinforced by stressing the clear legal distinction between tax legal avoidance and illegal tax evasion. Exit morality. But is it? States engaging in tax competition indeed bear responsibility for the lack of coordination of tax systems - although tax policy appears to respond primarily to those, such as MNCs with the resources to influence the policymakers (Christians 2017), this often amounts to "the substantive tax law shamelessness that marks much corporate tax lobbying” (Kleinbard 2013, 1517). Unfortunately, however, the notion of shared be it asymmetric - responsibility is not dealt with (Gribnau 2017b). It is not as if there are tax planning opportunities and therefore choices to be made that one is at liberty to do whatever one pleases. Morality simply does not work like that. Freedom of choice entails moral responsibility. Here, the moral responsibility means taking into account the difference between legitimately making use of opportunities present in the international tax system and engineering by setting up complex and artificial structures to minimize one's tax liability. Indeed, tax planning is a matter of degree, but at the end of the day, making use of choices to structure one's affairs in a tax efficient way has to be distinguished from exploiting the tax system - minimizing one's tax liability by all means. This lack of moral responsibility results in, for example, a stateless income, that is, "income that through internal tax planning, first becomes unmoored from the host country where it is earned and then 
sets sail for the tax haven of choice” (Kleinbard 2013, 1516; see $\S 5$ ).

Some positions seem to be more refined. For instance, Panayi, although she admits that the connection between CSR and taxes is almost inevitable (Panayi 2015, 558), tries to build a case against viewing tax in the context of CSR. Panayi, leaning on the forgotten role of other actors, such as states, in this context, does not agree that corporations that engage aggressive tax planning are socially irresponsible. She claims moreover that CSR is a vague concept that adds "further complexity and uncertainty to an already complicated area” (Panayi 2015, 544). Panayi argues also that "a company (or better, its management) in a high tax jurisdiction may be more justified in 'feeling' that it does not owe anything to the society and that it is acceptable to try to minimize its very high taxes and mitigate the impact of world-wide taxation" while "the management of a company in a jurisdiction which does not have such high taxes may not necessarily 'feel' that it owes more to society and that it should refrain from aggressive tax planning” (Panayi 2015, 555). This, however, suggests a misunderstanding of the essence of CSR. Namely, CSR is not about "feeling" that it is about being responsible towards a cooperative society that CSR companies claim to be. Being a part of the society includes the obligations to contribute in such society as well, next to the rights to enjoy the fruits of this society.

It thus is not a matter of what "is" (be it a kind of feeling), but what "ought". In the end, a company ought to behave (not only feel) responsible vis-à-vis society; that is exactly what business ethics and more specifically CSR is about. Companies that do not fulfil their obligations enjoy their benefit from society and all kinds of public goods at the cost of other members of this society; they are free riders. Naturally, it is a nuanced and complex issue, as Panayi correctly points out, and taxes are a cost item. However, claiming that CSR is an unjustified concept in this context is misleading. Especially the corporations that themselves already claim to be CSR companies cannot free ride on society's public goods and services by engaging in aggressive tax planning. Being a CSR company involves certain obligations towards the society and this has nothing to do with the 'feeling'. Naturally, it can be that there are trade-offs between different domains of corporate actions in relation to CSR (e.g., labor or environment). This, however is a subject for further research and is therefore not dealt with in this article.

Behaving ethically should be fundamental in all business matters, including tax planning practices. However, in order to foster a debate regarding what exactly is ethical, the companies should communicate about their prac- tices in tax matters, as this opens a door to discussion and paves the way toward a better understanding of tax morale. At the end of the day, aggressive tax planning cannot be resolved merely by changing the laws, for all laws can be gamed; it demands also that the mind-set and attitude are changed (McBarnet 2007, 48). In addition, extrinsic motivation, related to the reputation (see §6), can also support the moral outcomes of corporate actions. Almost inevitably, and legitimately, a company's tax behavior is driven by both intrinsic and extrinsic motives. However, if the aim is to be a true moral leader, the intrinsic motivation should prevail. This is the hallmark of good tax governance.

\section{Conclusion}

The aggressive tax planning practices of multinationals is currently a hotly debated topic. In the public debates, the behavior of multinationals is frequently evaluated in moral terms. Apparently, they are - like individuals - seen as a part of society. At stake is how the members of society should act in relation to each other, which is a moral issue. Like individuals, corporations qualify as moral agents. Therefore, companies must answer the question as to how one ought to act in relation to other individuals and society at large. Integrity demands that individuals think and act within a moral framework of principles and strategy to select these principles and deal with conflicts among them. Integrity means being guided by a set of ethical principles and values.

It is argued in this article that tax planning involves a moral stance because taxes are contributions to the society. Paying a fair amount of taxes is taking the values of reciprocity and solidarity seriously. Consequently, the concepts of "aggressive tax planning", "tax evasion" and "tax avoidance" express different relationships between law and morality. Notwithstanding their moral character, taxes are a cost item for any taxpayer. Moreover, taxpayers - thus, also corporations - have a right to structure their affairs to achieve a favorable tax treatment within the limits set by law. However, (corporate) taxpayers should balance this right with the duty of fair play towards society and thereby impose restraints on themselves in taking advantage of the inevitable imperfections of the legal system. By abstaining from aggressive tax planning, they take responsibility for the effects of their actions on society. Naturally, the state is primarily responsible for a better (legal) system. Nevertheless, perfect laws do not exist, as laws are always subject to interpretation. This suggests that multi- 
nationals face choices, which in turn implies responsibility for them as well.

It was shown that (aggressive) tax planning practices may affect a company's reputation. Moral decisions, on the other hand, have a positive impact on reputation and corporate legitimacy. Moral decision making in the context of tax planning entails going beyond minimalist compliance, beyond the letter of the tax law. This kind of ethical conduct beyond compliance fits well within a CSR-framework. Therefore, companies that seek to prove moral leadership can implement CSR policies. However, companies that already claim to have a CSR strategy in place must meet the expectations on good tax governance for taxes are contribution to a society.

When it comes to tax planning, the notion of "going beyond the compliance" consists of two layers, one procedural and the other substantive. A good - socially responsible - tax governance entails both. With regard to the substantive layer, based on Carroll's CSR Pyramid, socially responsible companies need to take into account ethical considerations in addition to legal and economic ones when defining and implementing a business strategy and taking tax-related decisions. The procedural layer involves the principle of transparency and thereby going beyond compliance with legal reporting obligations. Good tax governance is based on the intrinsic motivation to be transparent, which goes beyond a mere cost-benefit analysis and mere concern for reputation and market value.

\section{References}

ActionAid. April 2012. Calling Time: Why SABMiller Should Stop Dodging Taxes in Africa. http://www.actionaid.org.uk/doc_lib/calling_ time_on_tax_avoidance.pdf. Accessed 01 March 2017.

Avi-Yonah, Reuven. S. 2014. "Corporate Taxation and Corporate Social Responsibility." New York University Journal of Law \& Business 11 (1): 1-29.

Balakrishnan, Karthik, Jennifer L. Blouin, and Wayne R. Guay. 2012. "Does Tax Aggressiveness Reduce Corporate Transparency?" Working Paper (SSRN). https://papers.ssrn.com/sol3/papers2. cfm?abstract_id=1792783. Accessed 01 March 2017.

Benn, Suzanne, and Dianne Bolton. 2011. Key Concepts in Corporate Social Responsibility. London [etc.]: Sage Publications.

Bergin, Tom. 2012. UK Committees to Examine Starbucks Tax Strategies. Reuters (17 October 2012). http://articles.chicagotribune. com/2012-10-17/business/sns-rt-us-britain-starbucks-taxukbre89g0d9-20121017_1_hmrc-uk-tax-tax-law. Accessed 01 March 2017.

Bloomfield, Paul. 2007. "Introduction.” In Morality and Self-Interest, edited by Paul Bloomfield, 3-9. New York/Oxford: Oxford University Press.
Braithwaite, John. 2005. Markets in Vice, Markets in Virtue. Oxford: Oxford University Press.

Brown, Marvin T. 2005. Corporate Integrity: Rethinking Organizational Ethics and Leadership. Cambridge: Cambridge University Press.

Browning, Lynnley. 2007. "The Netherlands, the New Tax Shelter Hot Spot" New York Times (4 February 2007). http://www.nytimes.com/2007/02/04/business/yourmoney/ 04amster.html?pagewanted=all. Accessed 01 March 2017.

Callahan, Joan C. 1988. "Basics and Background." In Ethical Issues in Professional Life, edited by Joan C. Callahan, 3-25. New York: Oxford University Press.

Carroll, Archie B. 1991. "The Pyramid of Corporate Social Responsibility: Toward the Moral Management of Organizational Stakeholders." Business Horizons 34 (4): 39-48.

Carroll, Archie B. 1999. "Corporate Social Responsibility: Evolution of a Definitional Construct.” Business \& Society 38 (3): 268-95.

Carroll, Archie B. 2008. "A History of Corporate Social Responsibility: Concepts and Practices." In The Oxford Handbook of Corporate Social Responsibility, edited by Andrew Crane, Dirk Matten, Abagail McWilliams, Jeremy Moon, and Donald S. Siegel, 19-46. New York: Oxford University Press.

Castaldo, Sandro, Katia Premazzi, and Fabrizio Zerbini. 2010. "The Meaning(s) of Trust. A Content Analysis on the Diverse Conceptualizations of Trust in Scholarly Research on Business Relationships." Journal of Business Ethics 96: 657-68.

Cerioni, Luca. 2014. "International Tax Planning and Corporate Social Responsibility (CSR): Crucial Issues and a Proposed "Assessment" in the European Union Context." European Business Law Review 25 (6): 845-75.

Chang, Ha-Joon. 2010. 23 Things They Don't Tell You About Capitalism. London: Penguin.

Chen, Tao, and Chen Lin. 2015. "Does Information Asymmetry Affect Corporate Tax Aggressiveness?" Auckland University of Technology Working Paper August 2015. http: //www.aut.ac.nz/_data/assets/pdf_file/0007/595204/581156T-Chen-Information_TaxAvoidance_full15Aug2015.pdf. Accessed 01 March 2017.

Christian Aid. 2013. Giving with One Hand and Taking with the Other: Europe's Role in Tax-Related Capital Flight from Developing Countries 2013. http://www.christianaid.org.uk/images/Campaignstax-capital-flight-report-Dec-2013.pdf. Accessed 01 March 2017.

Christians, Allison (2017). "Trust in The Tax System: The Problem of Lobbying.” In Bruno Peeters, Hans Gribnau \& Jo Badisco (eds.), Building Trust in Taxation, 151-171. Cambridge: Intersentia.

Cockfield, Arthur J., and Carl D. MacArthur. 2015. "Country-byCountry Reporting and Commercial Confidentiality." Canadian Tax Journal/Revue Fiscale Canadienne 63 (3): 627-60.

Cohen, Gerald Allan. 2001. If You're an Egalitarian, How Come You're So rich? Cambridge (Mass.) \& London: Harvard University Press.

Crane, Andrew, and Dirk Matten. 2007. Business Ethics. New York: Oxford University Press.

Crane, Andrew, Dirk Matten, and Laura J. Spence. 2008. Corporate Social Responsibility: Readings and Cases in Global Context. London/New York: Routledge.

Court of Justice of the European Union. 2006. Case C-255/02 Halifax plc and others v. Commissioners of Customs \& Excise, [2006] ECR I-1609, para. 73.

Dahlsrud, Alexander. 2008. "How Corporate Social Responsibility is Defined: An Analysis of 37 Definitions." Corporate Social Respon- 
sibility and Environmental Management 15 (11): 1-13.

Davis, Gerald F., Marina von Neumann Whitman, and Mayer N. Zald. 2006. "The Responsibility Paradox: Multinational firms and Global Corporate Social Responsibility.” IPC Working Paper Series 4: 140.

De George, Richard. T. 1999. Business Ethics. Upper Saddle River: Prentice Hall.

Du, Shuili, C. B. Bhattacharya, and Sankar Sen. 2007. "Reaping Relational Rewards from Corporate Social Responsibility: The Role of Competitive Positioning." International Journal of Research in Marketing 24: 224-41.

Duff, David G. (2005) Private Property and Tax Policy in a Libertarian World: A Critical Review" Canadian Journal of Law and Jurisprudence 18: 23-46.

Eisenegger, Mark. 2009. "Trust and Reputation in the Age of Globalisation." In Reputation Capital, edited by Joachim Klewes and Robert Wreschniok, 11-22. Berlin: Springer.

Engskov, Kris. 2012a. "Starbucks Coffee Company in the UK (16 October 2012)." https://www.starbucks.co.uk/blog/starbucks-coffeecompany-in-the-uk/1238. Accessed 02 March 2017.

Engskov, Kris. 2012b. "An Open Letter from Kris Engskov (6 December 2012)." https://www.starbucks.com/blog/an-open-letterfrom-kris-engskov/1249. Accessed 01 March 2017.

European Commission Employment, Affairs \& Inclusion. Corporate Social Responsibility (CSR) in the EU. http://ec.europa.eu/social/ main.jsp?catld=331. Accessed 02 March 2017.

European Commission. 2011. "A Renewed EU Strategy 2011-14 for Corporate Social Responsibility." Communication From The Commission To The European Parliament, The Council, The European Economic And Social Committee And The Committee Of The Regions, Brussels 25 October 2011 COM(2011) 681 final. http://eur-lex.europa.eu/legal-content/EN/TXT/PDF/?uri=CELEX: 52011DC0681\&from=EN. Accessed 02 March 2017.

European Commission. 2012. Recommendation on Aggressive Tax Planning. C (2012) 8806 final, 6 December 2012. http://ec. europa.eu/taxation_customs/sites/taxation/files/resources/ documents/taxation/tax_fraud_evasion/c_2012_8806_en.pdf. Accessed 02 March 2017.

European Commission. 2015a. "A Fair and Efficient Corporate Tax System in the European Union: 5 Key Areas for Action". Communication from the Commission to the European Parliament and the Council, Brussels 17 June 2015 COM(2015) 302 final.

European Commission. 2015b. "Combatting corporate tax avoidance: Commission presents Tax Transparency Package." Press release. Brussels, 18 March 2015. http://europa.eu/rapid/press-release_ IP-15-4610_en.htm. Accessed 02 March 2017.

European Commission Taxation and Customs Union. 2015c. Action Plan on Corporate Taxation. http://ec.europa.eu/taxation_ customs/taxation/company_tax/fairer_corporate_taxation/ index_en.htm. Accessed 02 March 2017.

European Commission. 2016a. "Anti-Tax Avoidance Package: Next steps towards delivering effective taxation and greater tax transparency in the EU." Communication From The Commission To The European Parliament And The Council, Brussels 28 January 2016 COM(2016) 23 final. http://eur-lex.europa.eu/legal-content/ $\mathrm{EN} / \mathrm{TXT} / \mathrm{PDF} /$ ?uri=CELEX:52016DC0023\&from=EN. Accessed 02 March 2017.

European Commission. 2016b. "Proposal for a Directive of the European Parliament and of the Council amending Directive 2013/34/EU as regards disclosure of income tax information by certain undertakings and branches", Brussels 12 April 2016 COM(2016) 198 final. http://eur-lex.europa.eu/legal-content/EN/ TXT/?uri=CELEX:52016PC0198. Accessed 02 May 2017.

European Parliament.14 June 2006. Directive 2006/46/EC amending Council Directives 78/660/EEC on the Annual Accounts of Certain Types of Companies, 83/349/EEC on Consolidated Accounts, 86/635/EEC on the Annual Accounts and Consolidated Accounts of Banks and Other Financial Institutions and 91/674/EEC On the Annual Accounts and Consolidated Accounts of Insurance Undertakings. Of L 224/1, 16 August 2006. http://eur-lex.europa.eu/legal-content/EN/TXT/PDF/?uri= CELEX:32006L0046\&from=EN. Accessed 02 March 2017.

Financial Transparency Coalition. 2015. "OECD Country-byCountry Reporting: Only for the Strong?” (17 September 2015). https://financialtransparency.org/-country-by-countryreporting-only-for-the-strong. Accessed 01 March 2017.

Faulkner, Paul. (2017). "Is Taxation is on a Par with Forced Labour?" In Bruno Peeters, Hans Gribnau \& Jo Badisco (eds.), Building Trust in Taxation, 73-88. Cambridge: Intersentia.

Fisher, Colin, and Alan Lovell. 2009. Business Ethics and Values: Individual, Corporate and International Perspectives. ( $3^{\text {rd }}$ edition). Harlow: Prentice Hall.

Fombrun, Charles J. 1996. Reputation. Realizing Value from the Corporate Image. Boston (MA): Harvard Business School Press.

Frederick, William C. 1994. "From CSR1 to CSR2: The Maturing of Business-And-Society Thought.” Business \& Society 33 (2): 15064.

Freedman, Judith. 2006. “The Tax Avoidance Culture: Who Is Responsible? Governmental Influences and Corporate Social Responsibility." In Current Legal Problems, edited by Jane Holder and Colm O’Cinneide, 359-90. Oxford: Oxford University Press.

Freedman, Judith. 2014. "Defining Taxpayer Responsibility: In Support of a General Anti-Avoidance Principle.” British Tax Review 4: 332-57.

Friedman, Milton. 1970. "The Social Responsibility of Business is to Increase its Profits." New York Times Magazine. September, 13, 1970.

Gallemore John, Edward L. Maydew, and Jacob R. Thornock. 2014. "The Reputational Costs of Tax Avoidance." Contemporary Accounting Research 31 (4): 1103-33.

Garriga, Elisabet, and Doménec Melé. 2004. "Corporate Social Responsibility Theories: Mapping the Territory." Journal of Business Ethics 53 (1-2): 51-71.

Gert, Bernard. 1998. Morality: Its Nature and Justification. Oxford: Oxford University Press.

Global Reporting Initiative (GRI). About Sustainability Reporting. https://www.globalreporting.org/information/sustainabilityreporting/Pages/default.aspx. Accessed 01 March 2017.

Gray, Edmund R., and John M. T. Balmer. 1998. "Managing Corporate Image and Corporate Reputation." Long Range Planning 31 (5): 695-702.

Gribnau, Hans. 2014. "Not Argued from but Prayed To: Who's Afraid of Legal Principles?" eJournal of Tax Research 12 (1): 185-217. http://papers.ssrn.com/sol3/papers.cfm?abstract_id=2461247. Accessed 01 March 2017

Gribnau, Hans. 2015. "Corporate Social Responsibility and Tax Planning: Not by Rules Alone.” Social \& Legal Studies 24 (2): 225-50.

Gribnau, Hans, Ave-Geidi Jallai, and Anuschka J. Bakker. 2016. “Good Tax Governance and Transparency: A Matter of Reputation or Ethical Motivation?" Derivatives \& Financial Instruments 18 (1): 3-24. 
Gribnau, Hans. 2017a. "Voluntary Compliance Beyond the Letter of the Law: Reciprocity and Fair Play." In Rebuilding Trust in Taxation, edited by Bruno Peeters, Hans Gribnau, and Jo Badisco, 1750. Antwerpen: Intersentia.

Gribnau, Hans. 2017b. "The Integrity of the International Tax System after BEPS: A Shared Responsibility.” Erasmus Law Review (forthcoming)

Gutmann, Daniel. 2010. “L'évasion fiscale des sociétés.” Revue Internationale de Droit Comparé 62 (2): 533-51.

Hanlon, Michelle, and Joel Slemrod. 2009. "What Does Tax Aggressiveness Signal? Evidence from Stock Price Reactions to News about Tax Shelter Involvement." Journal of Public Economics 93: 126-41.

Happé, Richard. 2007. "Multinationals, Enforcement Covenants and Fair Share." INTERTAX 35 (10): 537-47.

Happé, Richard. 2015. "Ethics and International Tax Planning." In Tax Assurance, edited by Ronald Russo, 49-71. Deventer: Wolters Kluwer.

Hare, Richard Mervyn. 1992. Moral Thinking: Its Levels, Method and Point. New York: Oxford University Press.

Henry, James S. 2012. The Price of Offshore Revisited. Tax Justice Network. http://www.taxjustice.net/2014/01/17/price-offshorerevisited/. Accessed 01 March 2017.

The (UK) House of Commons, Committee of Public Accounts. 2012. (HMRC). "HM Revenue \& Customs: Annual Report and Accounts 2011-12. Nineteenth Report of Session 2012-13 Report, together with formal minutes, oral and written evidence." London: The Stationery Office Limited. http://www.publications.parliament. $\mathrm{uk} / \mathrm{pa} / \mathrm{cm} 201213 / \mathrm{cmselect} / \mathrm{cmpubacc} / 716 / 716 . \mathrm{pdf}$. Accessed 05 January 2017.

International Organization for Standardization (ISO). 2010. "Discovering ISO 26000." http://www.iso.org/iso/discovering_iso_ 26000.pdf. Accessed 01 March 2017.

International Organization for Standardization (ISO). ISO 26000 : Social Responsibility. http://www.iso.org/iso/home/standards/ iso26000.htm. Accessed 01 March 2017.

Ivey, Paula. 2010. "Reputation." In The A to Z of Corporate Social Responsibility, edited by Wayne Visser, Dirk Matten, Manfred Pohl, Nick Tolhurst, 337-339. Chichester: Wiley.

Jallai, Ave-Geidi. 2017. “Restoring Stakeholders' Trust in Multinationals' Tax Planning Practices with Corporate Social Responsibility (CSR)." In Rebuilding Trust in Taxation, edited by Bruno Peeters, Hans Gribnau, and Jo Badisco, 173-201. Antwerpen: Intersentia.

Jallai, Ave-Geidi and Hans Gribnau. 2017. "Free to Choose? Responsible Tax planning, Corporate Governance and Corporate Social Irresponsibility." TLS working paper, forthcoming.

Jøsang, Audun, Roslan Ismail, and Colin Boyd. 2007. "A Survey of Trust and Reputation Systems for Online Service Provision." Decision Support Systems 43: 618-44.

Kleinbard, Edward D. 2013. “Through a Latte Darkly: Starbucks' Stateless Income Planning." Tax Notes (24 June 2013), Center in Law, Economics and Organization Research Papers Series No. C13-9, Legal Studies Research Paper Series No. 13-10: 1515-35.

Kurucz, Elizabeth C., Barry A. Colbert, and David Wheeler. 2008. "The Business Case for Corporate Social Responsibility." In The Oxford Handbook of Corporate Social Responsibility, edited by Andrew Crane, Dirk Matten, Abagail McWilliams, Jeremy Moon, and Donald S. Siegel, 83-112. New York: Oxford University Press.

Lange, Donald, Peggy M. Lee, and Ye Dai. 2011. "Organizational Reputation: A Review.” Journal of Management 37 (1): 153-84.
Lewis, Stewart. 2003. "Reputation and Corporate Responsibility." Journal of Communication Management 7 (4): 356-366.

Machan, Tibor, R. 1999. "Business ethics in a free society." In A Companion to Business Ethics, edited by Robert E. Frederick, 88-99. Oxford: Blackwell.

McBarnet, Doreen J. 2007. "Corporate Social Responsibility Beyond Law, Through Law, For Law: The New Corporate Accountability." In The New Corporate Accountability: Corporate Social Responsibility and the Law, edited by Doreen J. McBarnet, Aurora Voiculescu, Tom Campbell, 9-56. Cambridge: Cambridge University Press.

Melé, Domènec. 2008. "Corporate Social Responsibility Theories." In The Oxford Handbook of Corporate Social Responsibility, edited by Andrew Crane, Dirk Matten, Abagail McWilliams, Jeremy Moon, and Donald S. Siegel, 47-82. New York: Oxford University Press.

Murphy, Liam, and Thomas Nagel. 2002. The Myth of Ownership. Taxes and Justice, Oxford University Press: Oxford.

Nouwen, Martijn F. 2017. "The European Code of Conduct Group Becomes Increasingly Important in the Fight Against Tax Avoidance: More Openness and Transparency is Necessary." INTERTAX 45 (2): 138-49.

Nozick, Robert. 1974. Anarchy, State and Utopia, Oxford: Basil Blackwell.

OECD (Organisation for Economic Co-operation and Development). 2013. “Addressing Base Erosion and Profit Shifting” (BEPS). Paris: OECD Publishing.

OECD (Organisation for Economic Co-operation and Development). 2015a. "Action 13: Country-by-Country Reporting - Implementation Package." Paris: OECD Publishing

OECD (Organisation for Economic Co-operation and Development). 2015b. "G20/OECD Principles of Corporate Governance." Paris: OECD Publishing.

OECD (Organisation for Economic Co-operation and Development). Corporate Social Responsibility: Frequently Asked Questions http://www.oecd.org/corporate/mne/ corporateresponsibilityfrequentlyaskedquestions.htm. Accessed 01 March 2017.

Paine, Lynn Sharp. 1994. “Managing Organizational Integrity.” Harvard Business Review 7 (2): 106-17.

Paine, Lynn Sharp. 1996. "Moral Thinking in Management: An Essential Capability.” Business Ethics Quarterly 6 (4): 477-92.

Panayi, Christiana H. J. I. 2015. “Is Aggressive Tax Planning Socially Irresponsible?" Intertax 43 (10): 544-58.

Perrini, Francesco, Sandro Castaldo, Nicola Misani, and A. Tencati. 2010. "The Relationship Between Corporate Responsibility and Brand Loyalty in Retailing: The Mediating Role of Trust.” In Global Challenges in Responsible Business, edited by N. Craig Smith, C. B. Bhattacharya, David Vogel, David I. Levine, 191-214. Cambridge: Cambridge University Press.

Piantavigna, Paolo. 2017. Tax Abuse and Aggressive Tax Planning in the BEPS Era: How EU Law and the OECD Are Establishing a Unifying Conceptual Framework in International Tax Law, Despite Linguistic Discrepancies. World Tax Journal 9 (01): 47-98.

Porter, Michael (interviewed by Mette Morsing). 2003. "CSR - a Religion with Too Many Priests?” European Business Forum 16: 7-8.

Rawls, John. 1999. A Theory of Justice (revised edition). Oxford: Oxford University Press.

Rawls, John. 2001. Justice as Fairness: A Restatement, edited by Erin Kelly. Cambridge (MA) \& London: The Belknap Press of Harvard University Press. 
Ruggie, John Gerard. 2013. Just Business: Multinational Corporations and Human Rights. New York: WW Norton \& Company.

Salazar, José, and Bryan W. Husted. 2008. "Principals and Agents: Further Thoughts on the Friedmanite Critique of Corporate Social Responsibility." In The Oxford Handbook of Corporate Social Responsibility, edited by Andrew Crane, Dirk Matten, Abagail McWilliams, Jeremy Moon, and Donald S. Siegel, 137-55. New York: Oxford University Press.

Schnackenberg, Andrew K., and Edward C. Tomlinson. 2016. “Organizational Transparency: A New Perspective on Managing Trust in Organization-Stakeholder Relationships." Journal of Management 42 (7): 1784-810.

Schwartz, Mark S. 2011. Corporate Social Responsibility: An Ethical Approach. Peterborough: Broadview Press.

Schwartz, Mark S., and Archie B. Carroll. 2003. "Corporate Social Responsibility: A Three-Domain Approach.” Business Ethics Quarterly 13 (4): 503-30.

SOMO. 2015. Tax-Free Profits: Welcome to the Geography of Tax Avoidance. https://www.somo.nl/wp-content/uploads/2015/12/ Tax-free-profits.pdf. Accessed 01 March 2017.

Stevens, Stan. 2014. "The Duty of Countries and Enterprises to Pay Their Fair Share." Intertax 42 (11): 702-8.

Stiglitz, Joseph E. 2002. "Information and the Change in the Paradigm in Economics." The American Economic Review 92 (3): 460-501.

Swift, Tracey. 2001. "Trust, Reputation and Corporate Accountability to Stakeholders." Business Ethics: A European Review 10 (1): 1626.

Ulrich, Peter. 2008. Integrative Economic Ethics: Foundations of a Civilized Market Economy. Cambridge: Cambridge University Press.

United Nations (UN). Information webpage on Tax Cooperation. http: //www.un.org/esa/ffd/topics/tax-cooperation.html. Accessed 21 February 2017.

United Nations (UN). 4 August 2016. "Promotion and Protection of Human Rights: Human Rights Questions, Including Alternative Approaches for Improving the Effective Enjoyment of Human Rights and Fundamental Freedoms." Seventy-first session Item 69 (b) of the provisional agenda of the General Assembly, A/71/286. http: //undocs.org/A/71/286. Accessed 21 February 2017.
Van den Hurk, Hans. 2014. "Starbucks versus the People." Bulletin International for Taxation 68 (1): 27-34.

Van der Geld, Jan. 2006. "De wet als enige werkbare norm in fiscaal-ethische zaken.” In Maatschappelijk heffen. De Wetenschap (Stevensbundel), edited by Dirk.A. Albregtse and Peter Kavelaars, 269-275. Deventer: Kluwer.

VBDO (Vereniging van Beleggers voor Duurzame Ontwikkeling). 2014. Good Tax Governance in Transition: Transcending the tax debate to CSR. http://www.vbdo.nl/files/media/VBDO_A5_Good_ Tax_Governance_D.pdf. Accessed 18 February 2017.

VBDO. 2015. Tax Transparency Benchmark 2015: A Comparative Study of 64 Dutch Listed Companies. http://www.vbdo.nl/files/news/ VBDO_TaxTransparencyBenchmark2015.pdf. Accessed 18 February 2017.

VBDO. 2016. Tax Transparency Benchmark 2016: A Comparative Study of 68 Dutch Listed Companies. https://www.aegon. com/contentassets/76c4906b17a1445786c6b59197784023/taxtransparency-benchmark-2016.pdf/. Accessed 18 February 2017.

Walker, Kent. 2010. "A Systematic Review of the Corporate Reputation Literature: Definition, Measurement, and Theory." Corporate Reputation Review 12 (4): 357-87.

Wan-Jan, Wan Saiful. 2006. "Defining Corporate Social Responsibility." Journal of Public Affairs 6 (3-4): 176-84.

Williams, Cynthia A., and Ruth V. Aguilera. 2008. "Corporate Social Responsibility in a Comparative Perspective." In The Oxford Handbook of Corporate Social Responsibility, edited by Andrew Crane, Dirk Matten, Abagail McWilliams, Jeremy Moon, and Donald S. Siegel, 452-72. New York: Oxford University Press.

Wood, Donna J. 1991. "Corporate Social Performance Revisited." Academy of Management Review 16 (4): 691-718.

YouGov Brandlndex. 21 November 2012. "Google is Spared the Public's Anger over UK Tax Spat.” http://www.brandindex.com/ article/google-spared-public\%E2\%80\%99s-anger-over-uk-taxspat. Accessed 01 March 2017.

YouGov BrandIndex. 2014. "2014 - Annual Rankings: UK Top Improvers.” http://www.brandindex.com/ranking/uk/2014-annual/ top-buzz-improvers. Accessed 01 March 2017. 